\title{
観覧車 会長·理事の手帳から
}

\section{「ふげん発電所」への思い}

理事(富士電機(㑣)）井 上 隆

ふげん発電所が来年には運転を停止する。誠に残念なこ とである。ふげん発電所はプルトニウムを準国産エネル ギー資源として利用できるように，国策として，国産技術 により開発された重水減速軽水沸騰型原子炉である。1970 年の着工当時, 国をあげて高度経済成長の達成に向けて邁 進を続けていた時期であり，産業界の総力をあげて建設に 取り組んだ経緯がある。この 2 月 $18 ， 19$ 日の両日，都内で 開催された「MOX利用国際セミナー」において，サイクル 機構からふげん発電所の運転実績について話を聞く機会を 得た。1979年からの本格運転以降，これまで23年間での累 積発電電力量は約207億 $\mathrm{kWh}$ であり，プルトニウム利用 という観点からは，累積726体の MOX 燃料利用の実績を あげた。これは世界の熱中性子炉での MOX 燃料利用実績 の約 $1 / 5$ を占め, 発電所単独では世界最高の利用実績であ り，加えて破損燃料は 1 体もないとのことである。建設に 係われた一人としてうれしい限りである。

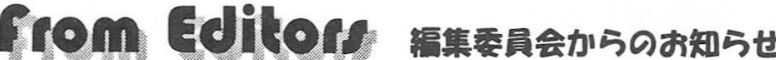

\section{一 ホームページ更新情報 — http://wwwsoc.nii.ac.jp/aesj/}

○和文論文誌の購読申込受付中。 ○第 4 回核融合エネルギー連合講演会 (6/13,14 阪大) プログラム

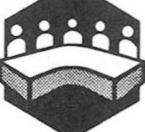

平成13年度第9回編集幹事会より

(2002 年 3 月 1 日(金) 14:00 17:30)

・談話室等記事掲載について，同一著者か らの多数回投稿があった場合，(1)会員の視点から見て多 くの会員が読むのにふさわしいもの，(2)できるだけ多く の会員が利用するもの，(3)社会的意義があるもの，(4)誌 面コストにふさわしい内容であるもの，に則って掲載す るかどうか決めることを確認した。

・専門委員会報告の取扱いについて議論し,専門委員会は, 2 年間の活動でどんな成果が得られたかという観点か ら，従来の資料，会報欄への掲載に替えて，2 ページ以 内の終了報告を掲載するよう，企画委員会に依頼するこ ととした。

・学会誌記事欄について検討した。「新技術・新製品紹介」 の内容については, 編集委員会が「新」とつけるべきレ
また核不拡散の立場で，プルトニウムの蓄積を過大にし ないという国際公約の実行という点で，ふげん発電所は大 いにその役割を果たしてきたといえる。言い換えれば，ふ げん発電所は, 日本が国際的に原子力平和利用を語る証し の一つとして，日本国民にとって世界に誇れる国家的財産 ともいえる。国の方針で運転停止が決定されてから約 4 年 になる。しかしながら，その後の原子力を取り巻く環境の 激变を誰が想定できたであろうか。「あんじゅ」のナトリウ ム漏洩事故後の高速炉開発のスローダウン, 英国 BNFLの MOX 燃料製造デー夕の改ざん事件, JCO 事故, 刈羽村住 民投票によるプルサーマル否決など。一連の逆風の中，軽 水炉でのプルサーマル化が足踏みを余儀なくされ，プルト ニウム利用の先行き不透明な現在，ふげん発電所での規模 的には小さいながらあ，プルトニウムを利用しつづけるこ との意義は何にも代えがたく大きいのではなかろうか。

不確実な時代にあって，国際的に核不拡散の実効を果た し続けていくためには，手段としての選択肢の多様化が肝 要であり，また，軽水炉のプルサーマル化を国民に理解し て頂くためにも，国民の財産である「ふげん発電所」という カードの有効性をあらためて考え直してみてはと思う。
ベルだと判断したものを対象とし「NEWS・TOPICS」 では概略を紹介する。「新技術・新製品紹介」では，企 業の PR ではなく，技術的な面に焦点を絞り，専門的な 視野に重きを置く。「原子力関係規制等の最新情報」は 今後, 内閣府諮問委員の協力を得て掲載していくことと した。

・「学会誌の記事収集」について提案があり，気軽に提案 できる環境作りが必要であること，幹事会では記事の内 容について議論する時間をもう少し増やすよう要望が出 された。また，掲載記事を中長期的に企画する必要性が あるとの意見が述べられた。

・年会・大会での座長より, 論文化提案だけでなく，解説 記事化提案があってもよいのではないか，潜在的な題材 を継続的に監視できる人を増やすべきであるとの意見が 出された。

・外国人エディターについて，4 月から運用予定であるこ とが紹介された。

・印刷経費等の現状報告があり，平成 13 年度は予算枠内 で運用できた。今後はさらにコスト意識を持って編集に 携わる必要があることを確認した。

事務局編集担当 TEL03-3508-1262 E-mail: office@aesj.or.jp 